\title{
Teacher education in the United Kingdom post devolution: convergences and divergences
}

\author{
Gary Beauchamp ${ }^{\mathrm{a} *}$, Linda Clarke $^{\mathrm{b}}$, Moira Hulme ${ }^{\mathrm{c}}$ and Jean Murray ${ }^{\mathrm{d}}$ \\ ${ }^{\mathrm{a}}$ Cardiff Metropolitan University; ${ }^{\mathrm{b}}$ University of Ulster; ${ }^{\mathrm{c}}$ University of Glasgow; ${ }^{\mathrm{d}}$ University of East London
}

\begin{abstract}
This paper examines the roles of research in teacher education across the four nations of the United Kingdom. Both devolution and on-going reviews of teacher education are facilitating a greater degree of cross-national divergence. England is becoming a distinct outlier, in which the locus for teacher education is moving increasingly away from Higher Education Institutions and towards an ever-growing number of school-based providers. While the idea of teaching as a research-based profession is increasingly evident in Scotland, Northern Ireland and Wales, it seems that England, at least in respect of the political rhetoric, recent reforms and explicit definitions, is fixed on a contrastingly divergent trajectory towards the idea of teaching as a craft-based occupation, with a concomitant emphasis on a (re)turn to the practical. It is recommended that research is urgently needed to plot these divergences and to examine their consequences for teacher education, educational research and professionalism.
\end{abstract}

Keywords: teacher education; research; devolution; professionalism

Corresponding author. Cardiff Metropolitan University, Cardiff School of Education, Cyncoed Rd, Cardiff CF23 6XD, UK. Email: gbeauchamp@cardiffmet.ac.uk )

(C) 2015 


\section{Introduction}

There is widespread international agreement that ' $(\mathrm{T})$ he quality of an education system cannot exceed the quality of its teachers and principals' (OECD, 2011, p. 235). Attention to the quality of teachers has directed attention to national systems for teacher education (OECD, 2005, 2007; Schleicher, 2011). Across the four nations of the United Kingdom (England, Northern Ireland, Scotland and Wales) teacher education is under active development and statutory requirements for initial teacher education (ITE) inevitably reflect assumptions about teaching and different approaches to the governance of teacher education. These changes have been facilitated by political devolution and possibilities for greater cross-national divergence in education policy have increased (Raffe, 2005). Reviews of teacher education have been undertaken in Northern Ireland (DEL, 2013; DENI, 2010a), Scotland (Donaldson, 2011), Wales (Tabberer, 2013) and, most significantly, England, where there have been multiple pronouncements on teacher education since the Coalition Government came to power in 2010 (e.g. DfE, 2010, 2011, 2013a-d). Revised standards/competences have been introduced in England (DfE, 2013a-c), Scotland (GTCS, 2012), Wales (WAG, 2009a; WG, 2011) and Northern Ireland (GTCNI, 2007). At the same time, university Schools of Education across the UK have experienced volatility in student numbers, institutional changes in Wales and a decline in the intake quota in Northern Ireland, destabilised staffing and fewer funding streams for applied research (Christie et al., 2012).

The actual range of providers for teacher education is diverse. In summary, ITE in Northern Ireland is currently provided through five higher education institutions (HEIs), two local universities and two university colleges, plus the Open University. There are no school-based routes into teacher education. From 2001 teacher education in Scotland has been provided through universities. There are currently eight university providers and no school-centred (SCITT) or employment-based (EBITT) routes. In Wales teacher training is provided by three regional 'centres', each made up of collaborating HEIs and, since 2013, Teach First Cymru. Each regional centre provides the opportunity to complete an accredited Initial Teacher Education and Training (ITET) course, as well as managing and delivering an allocated number of employment-based training routes under the Graduate Teacher Programme (GTP) on behalf of the Welsh Government. In England, the diversity of training routes is considerable. Even before the introduction of the School Direct route — in which schools recruit intending teachers and arrange their training — there were multiple providers and routes into teaching. In 2011/12, for example, Smithers, Robinson and Coughlin (2013) noted that ITE for approximately 35,790 recruits was supplied by 348 providers. This meant that 'over three quarters of students (76.4\%) were on university courses, nearly a fifth 
(18.9\%) of EBITT programmes but just under 1 in 20 in SCITTS (4.8\%)' (Smithers et al., 2013, p. i). The EBITT numbers include a small number of trainees enrolled on the Teach First route. ${ }^{i}$ The introduction of the School Direct route at scale has further complicated such patterns. Some form of post-graduate provision, however, looks set to remain the dominant mode of ITE, with School

Direct making the on-going involvement of some universities in teacher education uncertain (Furlong, 2013; McNamara \& Murray, 2013).

The paper draws on a cross-national review of such policies in the UK, originally undertaken in 2013, commissioned by BERA and the Royal Society for the encouragement of Arts, Manufactures and Commerce (RSA) and funded by BERA. It explores arrangements for ITE in the four jurisdictions of the United Kingdom. The paper has two major focuses: first, the declared teacher standards (competencies/competences) and their relationships to research-informed teacher education; and second, the 'turn to the practical' in teacher education, including policy declarations, changes in practice and emphases and effects of the discourse/s of relevance. Our focuses are therefore largely on explicit policy and practices or what Popkewitz (1987) terms 'the public discourses' of the sector across the UK. But following Ball (1994, p. 16), we would wish to acknowledge that public discourses of teacher education (including statements about teaching such as standards) are decoded, mediated and instantiated in practice in markedly differing ways across the teacher education sector. This is not least because they are shaped by and act to shape the perspectives of the various institutions providing teacher education and the trainees, serving teachers, teacher educators and other stakeholders operating in the field. In short and simple terms then, there are often differences and diversities in the ways in which teacher education policy is mediated and enacted in practice.

Our analysis identifies some similarities across the four jurisdictions, but it also demonstrates that policy in England appears to be diverging markedly from that elsewhere in the UK. This situation has particular implications for the future contribution of research-based knowledge in teacher preparation in England. But, despite these marked policy differences, many aspects of the nature (and quality) of teacher education in the four jurisdictions may not differ as much as political rhetoric, recent reforms and explicit definitions of teaching and teacher education might suggest. We return to discuss this issue in the conclusion to the paper.

\section{Methods and approach}

In the original review, policies outlining the teachers' standards/competences and statutory requirements for ITE were drawn from government sources and key agencies in each of the four nations: the Training and Development Agency for Schools (and where relevant, information from 
the previous versions of this agency, once known as the Teacher Training Agency) and the Department for Education in England; the Department for Education and Skills, Welsh Government; the Scottish Executive Education Department (SEED) and Scottish Government; the Department of Education (DENI) and the Department of Employment and Learning, (DEL) in Northern Ireland. Materials produced by the General Teaching Councils of Scotland, Wales and Northern Ireland were consulted; and, where appropriate, the publications of the school inspectorates (HMIE/Education Scotland, Ofsted, Estyn and the Education and Training Inspectorate Northern Ireland). In this paper we have updated our sources and reflected this in the revised commentary and analysis.

Our analysis is informed by the approach to 'home international' comparison advanced by Raffe and Byrne (2005). The explication of points of policy convergence and divergence is guided by the analytical framework proposed by Martens, Nagel, Windzio and Weymann (2010), supplemented by due attention to 'contextual comparison' (Seddon \& Levin 2013). Martens et al. (2010, p. 10) distinguish between policies (goals and instruments), education politics (modes and actors involved in decision making) and polities (institutional structure of decision making). In our analysis we recommend caution in reading practices of teacher education from standards/competences documentation and emphasise the significance of national institutional structures and guiding principles, political actors and veto players in the local mediation of policy. Moreover whilst the cross-national gaze adopted in this paper is necessarily restricted to the UK (through the BERA-RSA commission), we acknowledge the influence of global policy discourse on teacher education (Beech 2011; Paine \& Zeichner 2012).

\section{Teachers' standards/competences and research in national contexts}

The view of the teacher, and the role of research within ITE is depicted differently in the standards/competences frameworks across the UK. These documents frame perceptions of the 'good' or 'good enough' teacher and represent forms of 'prescribed' or 'demanded' professionalism (Evans, 2011). Our analysis shows that before 2011 the various standards across the UK shared a broadly common arrangement under three inter-related themes-professional values and practice, knowledge and understanding, and teaching skills. In each country there were differences in terms of provenance, content and precise language used, though with each set of standards carrying the inflection of local histories, politics and culture. Since then, although there are some communalities between the smaller countries in formulating and monitoring standards and competencies, there is a growing isolation of England, both in terms of rhetoric and expectation. 
In Scotland the General Teaching Council (established in 1965 and fully independent from 2012) has responsibility for the Entry Requirements (GTCS, 2013a), Guidelines for Initial Teacher Education Programmes (GTCS, 2013b) and Professional Standards (GTCS, 2012). These documents advise that applicants to ITE 'should have the capacity to know about research and scholarship and, where appropriate in the future, be actively able to practise research through, for example, professional enquiry' (GTCS, 2013a, p. 3). Engagement with research and participation in professional enquiry are woven through the revised Standards framework, which includes: Standards for Registration (SFR) — Provisional (ITE) and Full Registration (end of induction); Standard for Career Long Professional Learning (SCLPL); and, for some teachers, Standards for Leadership and Management. There is a movement from small-scale involvement in teacher research towards 'professional enquiry' linked to Professional Update for all registered teachers. The early phase standards require beginning teachers to know and understand 'the importance of research and engagement in professional enquiry' (GTCS, 2012, p. 12). The Standards for Registration (GTCS, 2012) require that NQTs (newly qualified teachers) 'know how to access and apply relevant findings from educational research; know how to engage critically in enquiry, research and evaluation individually or collaboratively, and apply this in order to improve teaching and learning' (p. 12). Beginning teachers are expected to 'systematically engage with research and literature to challenge and inform professional practice' (p. 18).

In Northern Ireland teacher education courses are approved by the Department of Education, accredited by the General Teaching Council for Northern Ireland (GTCNI) and inspected by the Education and Training Inspectorate (ETI) (DENI, 2010b). The GTCNI Code of Values and Professional Practice, in accord with the expectations in Scotland, advocates a reflective activist profession which is engaged in and with research:

\footnotetext{
The notion of the teacher as a researcher is complementary to the Council's concept of reflective practice. Teachers should engage in action research within their own classroom, school or institution and, in addition, they should take cognisance of research within the teacher education community. (GTCNI, 2007, p. 12)
}

Such views are framed by the Teacher Education in a Climate of Change consultation document (DENI, 2010a) which does mention an assortment of roles for research which include, inter alia, 'introducing new information and ideas to schools; encouraging teachers to engage more actively with new knowledge and approaches ... how best teachers can be educated ... teaching methodologies that lead to effective learning ... and ...ensuring that the findings from this work are reflected in all stages of teacher education'. Helpfully, it is also suggested that 'research priorities 
need to be developed and taken forward in a comprehensive and coherent manner and DE needs to form a closer relationship with the producers of research' (DENI, 2010a, p. 17). Obtaining funding for research in education in Northern Ireland will become more difficult with the forthcoming withdrawal of two major US-based philanthropic providers, so a role for DE in supporting education research is to be welcomed. Despite this, however, Leitch (2008, p. 111) has suggested that 'the role of practitioner research is significantly under-utilised in terms of knowledge production, teacher development and school improvement'. Moran (2013) highlights the current individual and institutional competiveness for limited funding, arguing that this might be usefully replaced by inter-institutional research consortia which would serve to maximise the impact of local expertise.

In Wales, the position of research is currently less explicit, although the recent Tabberer (2013) review suggests that 'the current position, whereby research has a low status in a professional training environment, is un-tenable.' (p. 25). At present, all ITE programmes, predominantly post-graduate routes, are accredited by the Higher Education Funding Council for Wales (HEFCW). The General Teaching Council for Wales (GTCW) is responsible for the notification of award of Qualified Teacher Status (QTS) on behalf of the Welsh Government and inspections are undertaken by Estyn (Her Majesty's Inspectorate for Education and Training in Wales), who inspect the three regional 'centres' rather than individual providers. QTS standards were revised in 2009 to take into account the specific curricular requirements introduced by the Welsh Government, especially the Foundation phase (which replaced Key Stage 1 for 3-7 yearolds), introduced from 2008 and fully implemented in 2012. These standards are organised into three interrelated sections (Professional Values and Practice; Knowledge and Understanding; Teaching), whatever route is taken into teaching. Significantly, the 2009 standards themselves contain no explicit reference at all to academic (or indeed any) research, although there is an expectation that teachers should be 'confident and authoritative in the subjects they teach'. The standards are supplemented by non-statutory guidance (WAG, 2009b), which suggests teachers 'should show an awareness of where to find, and how to critically engage with, evidence from sources such as research and inspection reports' (WAG, 2009b, p. 23) and that 'Trainees could also demonstrate their knowledge through written assignments, small-scale research activities and school-based tasks' (p. 46).

This is, however, at odds with the inspection guidance for ITE given to providers by Estyn (2012) where research, at least by ITE staff, features much more prominently. For instance, there are suggestions that 'Good teaching/training' should be 'well informed by research' (p. 25), the inspection team 'will consider the ITE provider's ability to be at the cutting edge of ITE through 
'horizon scanning', collaborative ventures and educational research' (p. 32) and 'Inspectors will take account of the extent to which senior leaders of ITE create opportunities for their staff to engage in teacher education focused research which enhances courses offered' (p. 37). It should be noted this relates to ITE staff, and no mention is made of how trainees will use research, although 'the inspection team will also take account of how well trainees develop good independent learning skills including research, critical analysis and problem-solving skills.' (p. 17)

ITE in England, once accredited by various iterations of the government quango latterly called the Teaching Agency, is currently overseen by the National College of Teaching and Leadership and regulated by Ofsted (the English Office for Standards in Education, Children's Services and Skills). The value of research in teacher education in England is contested, and current government policy gives distinctly mixed messages about it. Overall, this paper sees the importance of research-informed provision in England as diminishing over time, with the knowledge base for teaching often defined as practical, relevant and focused around contemporary, experiential knowledge of schooling.

Particularly at post-graduate level, there is little explicit inclusion of research-informed knowledge from the four traditional disciplines of education (history, philosophy, psychology and sociology) in the ITE curriculum offered by most training providers. Increased time is now spent in the classroom on practicum (usually a minimum of two thirds of the ITE programme). Furlong (2013) argues that the rapid growth of post-graduate ITE routes (replacing degree courses for teachers, with emphases on both personal and professional education) has accelerated this tendency for more time in the classroom, as has the overwhelming focus of the curriculum on preparation and support for the practicum. But, even in post-graduate ITE, where little time is allowed for study in the university, it should be noted that most university-led provision has maintained a commitment to combine perspectives from educational research with meeting the official imperatives of making programmes 'demanding, relevant, and practical' (Furlong, Barton, Miles, Whiting, \& Whitty, 2000, p. 144). Many programmes also draw explicitly on practitioner enquiry or action research modes of learning for trainees.

The 33 English Teacher Standards of 2007, which contained some clear emphases on research-informed professionalism (TDA, 2007, pp. 8, 27), were replaced in 2012 by just eight standards for Qualified Teacher Status (QTS), although each of these had various sub-clauses. In general, the focus of these standards is predominantly on 'teachers' behaviour, rather than on their attitudes and their intellectuality' (Evans, 2011, p. 851). They are written in what Connell et al (2010) have described as the language of corporate managerialism, with the good teacher 
constructed as entrepreneurial and possessed of identifiable skills and attributes which will enable her or him to perform as an effective professional. These standards include a new focus on teacher commitment in 'not undermining fundamental British values, including democracy, the rule of law, individual liberty and mutual respect, and tolerance of those with different faiths and beliefs' (DES, 2013). The standards do expect that beginning teachers will 'demonstrate knowledge and understanding of how pupils learn and how this impacts on teaching', but the principal focus in terms of a knowledge base for teaching is possession of 'good subject and curriculum knowledge'. The ethical dimensions involved in learning to teach (Mahony, 2009) are certainly downplayed here. There is also little explicit reference to teachers' engagement with (and in) research or curriculum enquiry, although we should note that some commentators have identified implicit references to the use of research-based knowledge and research-related activities such as critical reflection and collaborative enquiry' (BERA-RSA, 2014, p. 15) in certain of these standards.

Overall, the 2012 standards in England are seen here as predominantly skills-based, indicating a decisive shift away from the idea of teaching as a research-based profession and intellectual activity towards teaching as a craft-based occupation, an issue to which we will return below. These standards are also defined as regulatory rather than developmental in intent (Mahony \& Hextall, 2000).

$\$$

From our analyses of the four sets of standards currently in use across the UK, we see the concept of 'performative professionalism' as evident to some extent in all, but is demonstrated most clearly in England. This was a recurring theme in analyses of New Labour discourses on teaching (Beck, 2009; Evans, 2011). Beck (2009, p.8), for example, suggests that:

The performative emphasis is what dominates Professional Standards for Teachers. This is manifest not only in the content of the individual standards, but also in the discourse that frames them...The cumulative effect of this form of discourse is profoundly reductive: it suggests that being a professional educator is a matter of acquiring a limited corpus of state prescribed knowledge accompanied by a set of similarly prescribed skills and competencies. The model is a technicist one involving the acquisition of trainable expertise.

\section{The (re)turn to the practical and the discourse/s of relevance}

Furlong \& Lawn (2011, p. 6) refer to current trends in teacher education as representing a 'turn to the practical'. Many of these trends towards placing more importance on the 'practical' and 
'relevant' aspects of teacher education, particularly the practicum, are found across the UK as a whole. But in England such trends have been intensified by specific structural and political factors and by a culture of compliance and regulation which often dominates teacher education and its providers (Menter, Brisard \& Smith, 2006).

The 'discourse of relevance' (Maguire \& Weiner, 1994) is a powerful part of the (re)turn to the practical in that it brings an intensification, re-orientation and simplification of professional knowledge to focus - in the main - on contemporary practice in schools (Furlong, 2013). Although Maguire \& Weiner (ibid) refer only to 'discourse' in the singular, our analysis indicates that there are many forms and iterations of this discourse in the UK. These are sometimes very specific to each country, where, for instance, the language and rhetoric employed to discuss 'relevance' reflect differing views of the teacher and teacher education. For example, the explicit language of relevance, often dominant within recent official documentation and public pronouncements in England, may be contrasted with more subtle nuances in the policy language for pre-service programmes in Northern Ireland and Scotland. These generally use the term 'teacher education' rather than 'training' and, as we indicate in this paper, emphasise the importance of broad, researchinformed knowledge bases for teaching. But they also still orientate large parts of courses towards preparation for the experience of the practicum and actual time teaching in classrooms. A significant part of the various discourses of relevance relates then to political understanding of the nature of teaching and the experiential skills and knowledge envisaged as necessary for new teachers to be 'classroom-ready', that is fully prepared for teaching in contemporary schools, immediately after completing ITE courses.

The process of devolution in particular has allowed a growing polarisation reflecting national identities and how education can help each particular nation reflect and develop this identity. For instance, although for many years there was little difference between the education policy of England and Wales (Jones, 1997; Daugherty et al, 2000), devolution of limited powers has led to a divergence of policy to reflect a distinctive 'made in Wales' agenda (Davidson, 2004) aiming to 'transform education and lifelong learning in post-devolution Wales.' (WAG, 2008, p.1) In this context both the curriculum and teacher training need to reflect the aspiration of Wales to be a bilingual 'learning country' (WAG, 2004), where ITE services both Welsh and English medium schools. (Likewise, there is provision for ITE for Irish language schools in NI at both primary and post primary level.) Such policies in Wales are the result of 'a long period of intellectual soul searching about Welsh identity' (Daugherty \& Davies, 2011, p.5) and also reflect the belief that 'Wales has particular needs that require distinctive policy solutions' (Ibid.) - an argument that 
could perhaps be made for all nations in this study. The resultant government aim of education in Wales is to 'help everyone reach their potential, reduce inequality, and improve economic and social well-being.' (Welsh Government, 2014)

The nature of the discourses in Scotland and Northern Ireland also reflects broader concerns about social justice and cultural contexts of the individual countries and, in Scotland, a continuing commitment to community comprehensive education and the 'tradition' of the 'democratic intellect' (Davie, 1961). In Scotland, 'maximising relevance and impact' is a core theme within the Donaldson report on teacher education (2011), both in early phase and career-long professional learning. The report recognises that in order to address the 'wicked issues' that persist in Scottish education (that is, social inequalities in participation and achievement) professional preparation needs to 'go well beyond recreating the best of past or even current practice' (p. 4). Part of the response to this is found in the reform of the traditional 'academic' school curriculum with the more socially inclusive and flexible Curriculum for Excellence (Raffe, 2008).

Broader social issues and long standing sectarian divisions are not ignored in relevant competences for teacher education in Northern Ireland, but neither are they necessarily resolved. The second (of 27) professional competence requires teachers to develop a knowledge and understanding of contemporary debates about the nature and purpose of education, and the eighth has more distinctive local relevance in requiring a knowledge and understanding of the need to take account of pupils' cultures, languages and faiths. In addition, providers of ITE courses are required to ensure that their 'programmes prepare students to address the strategic priorities for education and key education strategies, as defined and communicated by DE' (DENI, 2010b, p.5). In recent years the key priorities have matched DENI's priorities for the wider education system: literacy, numeracy and special educational needs and inclusion. The inertia which has characterized much of the postdevolution political milieu in Northern Ireland has meant that distinctive local issues such as preparing student teachers to deal with controversial sectarian issues and the compulsory nature of an almost wholly Christianity-focused religious education provision (Montgomery \& Smith, 2006) in primary teacher education courses, have not been addressed at policy level.

In England, although there has been debate about national identity and values within the standards and the ITE curriculum, there is a significant move to a generic stance, superficially less influenced by cultural beliefs and more by ideological agendas. As indicated earlier, there has been a strong tendency to '(re)turn to the practical', in large part as a result of government intervention in the governance, monitoring and regulation of ITE, with legislative changes dating back to 1984. At the time of writing this tendency is accelerating with the deregulation of the schooling system and the 
introduction of the School Direct programme (McNamara \& Murray, 2013). These reforms proceed alongside changes in key agencies with responsibility for teacher education, shifts in long established partnerships between universities and schools, changes to the school curriculum and national assessment and to teachers' conditions.

Over the past 30 years then, ITE in England has become highly politicised, positioned as an effective mechanism to transform teaching and teacher professionalism and steer change in schools (Furlong et al, 2000). Recent governments - of all political persuasions - have worked to change the control and locus of teacher education from the academy into the classroom, around a predominantly practical, relevant and school-led curriculum and assessment framework (McNamara \& Murray, 2013). The raft of recent declarations indicate that current policy in England is underpinned by what McNamara \& Murray (ibid, p.22) state is 'an understanding of teaching as a) essentially a craft ${ }^{\mathrm{ii}}$ rather than an intellectual activity; b) an apprenticeship model of teacher training that can be located entirely in the workplace; and c) the related assumption that more time spent in schools inevitably - and unproblematically - leads to better and 'more relevant' learning.' But we would also reiterate our earlier point that most university-led provision has maintained a commitment to combine perspectives from educational research, alongside meeting official requirements for a model of teacher education which potentially 'privileges performativity and 'practical' knowledge over theoretical, pedagogical and subject knowledge' (ibid).

To complicate the picture further, other government policy initiatives give a different message in terms of valuing the place of research-informed teacher education, including teacher engagement in research and 'Evidence-Based Teaching'. As the BERA-RSA Interim Review (2013) notes, ofparticular significance here are the following initiatives from the English Department for Education (DfE): the establishment of a national network of Teaching Schools, which now lead teacher development, with the aim of raising the profile of teacher research; an enhanced emphasis on creating an evidence base of research for teaching, in part drawing on evidence gained from randomised control trials funded by the Education Endowment Fund; and the establishment of limited number of university-led Teaching Schools. The effects of these new initiatives could potentially be transformative, as some commentators have noted (see Husbands, 2013) But only time will tell if they will genuinely strengthen research-informed modes of teacher education, and if and how the high valuation of research in these government initiatives will 'win out' over more technical-rational formulations of teacher knowledge as predominantly experiential and craft-based in other pronouncements (see, for example, Gove, 2010) As well as noting these mixed messages in government policy, we would also note that there is a certain irony in the establishment of these new structures at the same time as many university Schools of Education, the conventional homes 
of research-informed modes of teacher education over decades, are facing threats to their capacity and sustainability (Furlong, 2013), as this new 'market-led' system of teacher education evolves and sources of educational research funding change.

In sharp contrast to developments in England, Teaching Scotland's Future (Donaldson, 2011) argues that preference for apprentice models of work-based learning among beginning teachers is to be challenged: 'The values and intellectual challenges which underpin academic study should extend their own scholarship and take them beyond any inclination, however understandable, to want narrow training of immediate and direct relevance to life in the classroom' (p.6). It is suggested that:

The 'craft' components of teaching must be based upon and informed by fresh insights into how best to meet the increasingly fast pace of change in the world which our children inhabit. Simply advocating more time in the classroom as a means of preparing teachers for their role is therefore not the answer to creating better teachers. The nature and quality of that practical experience must be carefully planned and evaluated and used to develop understanding of how learning can best be promoted in sometimes very complex and challenging circumstances. (Donaldson, 2011, pp. 4-5)

Undergraduate ITE programmes in Scotland have been revised in response to Donaldson's critique (2011, p.39) that the traditional BEd degree had, 'an over-emphasis on technical and craft skills at the expense of broader and more academically challenging areas of study.' Successor qualifications to the BEd were put in place in 2014. It is argued that the university location of Schools of Education might be more fully exploited to reduce 'unhelpful philosophical and structural divides, [which] have led to sharp separations of function amongst teachers, teacher educators and researchers' (p.5). Whilst highly valued, the practicum should be the site for experimentation in 'well researched innovations' by 'research aware teachers' (p.102). School experience 'should do much more than provide practice in classroom skills, vital though these are. Experience in a school provides the opportunity to use practice to explore theory and examine relevant research evidence' (p.90). Teaching Scotland's Future recommends the creation of a network of 'hub teaching schools as a focal point for research, learning and teaching' (p.91, pp.111-112). In contrast to the model of Teaching Schools adopted in England (Matthews \& Berwick, 2013), 'hub schools' extend a role for university-based educators in partnership with strong local authorities. The aim is to promote "much more direct engagement of university staff in school practice, with research as an integral part of this strengthened partnership rather than as something which sits apart' (Donaldson, 2011, p.8).

\section{Conclusion}


This review of policy and practice in all four jurisdictions over the last decade indicates that the content, location, control and quality of teacher preparation has been the focus of sustained debate across the UK. It suggests past and present areas of similarity as well as some recent and marked divergence, with England emerging as the outlier. In Scotland, Northern Ireland and Wales education is clearly important in the construction of developing and/or re-affirming national identities. Teacher education policy assumes particular strategic importance in devolved governments. Across the UK, sets of standards/competence frameworks set out minimum expectations. These standards/competences vary in the extent to which they are generated within and by the profession, and the ways in which they are instantiated in practice either as tools to support teachers' professional development or as regulatory measures to hold emerging and serving professionals to account (Mahony \& Hextall, 2000). The knowledge base of teaching is contested in all four jurisdictions, and the standards clearly reflect different, declared conceptions of teaching and the professional knowledge of teachers.

In Scotland and Northern Ireland, and less explicitly in Wales, research-informed provision is a declared part of the expectations of teacher education programmes and providers. Notably, in Scotland the intellectual challenge of personal and professional education in undergraduate programmes for prospective primary teachers has been strengthened. In contrast, in England, the place of research-informed teacher education is contested. As indicated, the designation of teaching as a craft has undoubtedly led some to simplify teacher knowledge and the processes of learning to teach in policy pronouncements, with a seeming devaluation of the overall place of research in teacher learning resulting. The simplified and revised version of the teachers' standards (2012) in England is seen here as consistent with a wider ideological critique of 'progressive educational theory' that positions university-based teacher education and its educators as 'enemies of promise' (Gove, 2013). Yet, there are also distinctly mixed messages in government policy about the valuation given to research-informed teacher education, with the research and development brief for Teaching Schools being potentially transformative. Varying - and sometimes seemingly contradictory - practices around research and teacher education may, in the views of the authors of this paper, be attributed in some part to the ways in which the mixed messages in government policy for research and teacher education are mediated and instantiated in practice in England. This is a particular factor because, as we have noted, the Higher Education sector, with its commitment to research-informed modes of teacher education, has long been a powerful stakeholder in the field. Evidence of this differentiation can be found in many accounts of the research-informed richness which - against the policy background outlined in this paper - many universities in England have 
continued to provide with their partnership schools for the benefit of their pre- and in-service teachers (see Childs et al, 2013; Wilson, 2012).

Historically, across the UK there have been close relationships between educational research and the nature of teacher education provision, particularly ITE, (Furlong, 2013), but it is clear that those relationships are currently in flux. This situation is of particular concern in England, where the introduction of the School Direct route threatens the maintenance of current models of researchinformed teacher education in many universities. It is feared that School Direct will threaten the financial stability of Schools of Education and their institutional abilities to plan strategically, leading to the increased casualisation of the teacher education workforce and the loss of researchinformed knowledge and skills for high quality teaching and teacher education (McNamara \& Murray, 2013). But within a general pattern of sharply reduced funding for all education research across the whole UK, there has been a noticeable decline in the funding for research in and on teacher education, accessible to university Schools of Education (Christie et al, 2012). Funding for research capacity building in this area has also not been sustained (Menter \& Murray, 2009). And, given the dearth of large-scale and longitudinal studies in the 'young' field of teacher education research (Menter et al, 2010), there is as yet limited evidence on which to base judgements about the effectiveness of teacher education, in its various forms. This situation also means that there is also only limited evidence on how far policy differences are - or are not - reflected in the mediated content and practices of teacher education programmes across the UK. Despite renewed emphasis on the importance of evidence-based policy and practice (DfE, 2013d) in England, for example, the current direction of reform makes only selective use of research on teacher education itself (Morris, 2012). In Scotland and Wales the nature of teachers' future engagement with research is uncertain, although the aims, purpose, design and funding of 'Masters level' (accredited) professional learning is the subject of continued deliberation. The GTCNI has been an advocate of a Masters level profession in NI, the matter has been discussed at UCETNI and is supported by the ETI - but the matter has fallen off the agenda of late, replaced by the infrastructural concerns.

Our analysis in this paper has identified both similarities and differences across and between the four jurisdictions, but it has also demonstrated that policy in England appears to be diverging from that elsewhere in the UK. But, despite the appearance of such policy divergence, the nature (and quality) of the actual provision of teacher education in the four jurisdictions may not differ as much as political rhetoric, recent reforms and explicit definitions of teaching and teacher education might suggest. In the absence of clear research-informed evidence on the effectiveness and lived realities of the many and various research-informed teacher education programmes across the UK, we can 
only conclude this paper with our professional judgements. These are that, in these times of economic austerity, opportunities for maintaining research-informed and enquiry-led professional learning are welcome, as is debate on the contribution of the rich variety of research undertaken in universities in partnership with the teachers, schools and communities they serve.

\section{Acknowledgements}

A longer version of this article was developed as a background paper for the 2013 BERA/RSA Inquiry on the contribution of research in teacher education and school improvement, and can be found in the BERA website.

\section{References}

Ball, S. (1994). Education Reform: a critical and post-structural approach. Buckingham: Open University Press.

Beck, J. (2009) Appropriating professionalism: restructuring the official knowledge base of England's 'modernised' teaching profession, British Journal of Sociology of Education, 30(1), 314.

Beech, J. (2011) Global Panaceas, Local Realities. International Agencies and the Future of Education. Frankfurt, Peter Lang.

BERA RSA (2014) The Role Of Research In Teacher Education: Reviewing The Evidence Interim Report Of The BERA-RSA Inquiry. London: BERA.

Childs, A., Edwards, A. \& McNicholl, J. (2013) Developing a Multi-layered system of distributed expertise: what does cultural historical theory bring to understanding workplace learning in schooluniversity partnerships? In McNamara, O., Murray, J. \& Jones, M. (editors) Workplace Learning in Teacher Education. London: Springer.

Christie, D., Donoghue, M., Kirk, G., McNamara, M., Menter, I., Moss, G., Noble-Rogers, J., Oancea, A., Rogers, C., Thomson, P. \& Whitty, G. (2012) BERA-UCET Working Group on Education Research. Prospects for Education Research in Education Departments in Higher Education Institutions in the UK. Available: http://www.bera.ac.uk/news/bera-ucet-report.

Connell, R., Campbell, C., Welch, A., Bagnall, N., Hayes, D., Vickers, M. \& Foley, D. (2010) Education, Change and Society. (2nd ed.), South Melbourne: Oxford University Press Australia. 
Daugherty, R., Phillips, R., \& Rees, G. (2000) Education Policy Making in Wales: Explorations in devolved governance. Cardiff: University of Wales Press.

Daugherty, R. \& Davies, S.M.B. (2011) Capacity and Quality in Education Research in Wales. The Welsh Journal of Education, 15, 4-23

Davidson, J. (2004) Distinctive Education Policies in Wales. Forum, 46(2): 46-51.

Davie, G.E. (1961) The Democratic Intellect. Edinburgh: Edinburgh University Press.

Department of Education Northern Ireland [DENI] (2010a) Teacher Education in a Climate of Change (Teacher Education Review) http://www.deni.gov.uk/index/school-staff/teachersprofessional-development/4-teachers-teachereducationreview pg.htm.

Department of Education Northern Ireland [DENI] (2010b) Initial Teacher Education: Approval of Programmes: Circular Number 2010/03 (superseding DE Circular 1989/40)

http://www.deni.gov.uk/ite approval of programmes circular - english version-2.pdf.

Department for Education [DfE] (2010) The Importance of Teaching. The Schools White Paper 2010. Cm 7980. London: The Stationery Office.

Department for Education [DfE] (2011). Hundreds of teachers awarded national scholarships. www.education.gov.uk/inthenews/inthenews/a00200774/hundreds-of-teachers-awarded-nationalscholarships. Accessed 2 October 2012.

Department for Education [DfE] (2013a) Teachers' Standards. http://media.education.gov.uk/assets/files/pdf/t/teachers\%20standards\%20information.pdf. Department for Education [DfE] (2013b) Teachers' Standards. How should they be used? http://media.education.gov.uk/assets/files/pdf/t/info $\% 20$ sheet $\% 20$ how $\% 20$ should $\% 20$ they $\% 20$ be $\%$ 20used\%20170413.pdf.

Department for Education [DfE] (2013c) Research Priorities and Questions: Teachers and Teaching. June 2013. Available: https://www.gov.uk/government/publications/research-prioritiesand-questions-teachers-and-teaching.

Department for Education [DfE] (2013d) School workforce in England. November 2012. SFR 15/2013. 
https://www.gov.uk/government/uploads/system/uploads/attachment_data/file/193090/SFR 15 201 3.pdf.

Department for Employment and Learning [DEL] (2013) (Grant Thornton, 2013) Study of the Teacher Education Infrastructure in Northern Ireland. http://www.delni.gov.uk/teacher-educationinfrastructure-ni-study.pdf.

Donaldson, G. (2011) Teaching Scotland's Future. Edinburgh: Scottish Government.

Estyn (2012) Guidance for the inspection of initial teacher training from 2010 (Revised 2012) http://www.estyn.gov.uk/english/inspection/inspection-guidance/initial-teacher-education-andtraining/ (accessed 06/10/13).

Evans, L. (2011) The 'shape' of teacher professionalism in England: professional standards, performance management, professional development and the changes proposed in the 2010 White Paper. British Educational Research Journal, 37(5), 851-870.

Furlong, J., Barton, L., Miles, S., Whiting, C., \& Whitty, G. (2000) Teacher Education in Transition. Buckingham: OUP.

Furlong, J. \& Lawn, M. (eds) (2011) Disciplines of Education: their role in the future of education research. London: Routledge.

Furlong, J. (2013) Education: an anatomy of the discipline. London: Routledge.

General Teaching Council of Northern Ireland [GTCNI] (2007) Teaching: The Reflective Profession. Belfast: GTCNI.

http://www.gtcni.org.uk/uploads/docs/gtcni_comp bmrk\%20\%20aug\%2007.pdf.

General Teaching Council for Scotland [GTCS] (2012) The Standards for Registration: mandatory requirements for Registration with the General Teaching Council for Scotland. December 2012. http://www.gtcs.org.uk/web/FILES/the-standards/standards-for-registration-1212.pdf.

General Teaching Council for Scotland [GTCS] (2013a) Memorandum on Entry Requirements to Programmes of Initial Teacher Education in Scotland. http://www.gtcs.org.uk/web/FILES/aboutgtcs/memorandum-on-entry-requirements-to-programmes-of-ite-in-scotland-0413.pdf. 
General Teaching Council for Scotland [GTCS] (2013b) Guidelines for Initial Teacher Education Programmes in Scotland. http://www.gtcs.org.uk/web/FILES/about-gtcs/guidelines-for-iteprogrammes-in-scotland-0413.pdf.

Gove, M. (2010). Speech to the Annual Conference of the National College for Leadership of Schools and Children's Services. Birmingham, 16 June.

www.education.gov.uk/news/news/nationalcollege. Accessed 12 July 2012.

Gove, M. (2013) I refuse to surrender to the Marxist teachers hell-bent on destroying our schools: Education Secretary berates 'the new enemies of promise' for opposing his plans. Mail on Sunday, 23 March 2013. http://www.dailymail.co.uk/debate/article-2298146/I-refuse-surrender-Marxistteachers-hell-bent-destroying-schools-Education-Secretary-berates-new-enemies-promiseopposing-plans.html.

Husbands

Jones, G.E. (1997) The Education of a Nation. Cardiff: University of Wales Press.

Leitch, R. (2008) Capacity and Quality in Education Research in Northern Ireland. Strategic Forum for Research in Education. Forum I Stimulus Reports, pp. 93-125.

Maguire, M. \& Weiner, G. (1994) The place of women in teacher education: Discourses of power. Educational Review. 46.2: 121-139.

Mahony, P. (2009) Should 'ought' be taught? Teaching and Teacher Education, 25, 983-989.

Mahony, P. \& Hextall, I. (2000) Reconstructing Teaching: Standards, Performance and Accountability. London: Routledge Falmer.

Martens, K., Nagel, A., Windzio, M. \& Weymann, A. (ed.s) (2010) Transformation of Education Policy. Basingstoke: Palgrave Macmillan.

Matthews, P. \& Berwick, G. (2013) Teaching schools: first among equals? Nottingham: National College for Teaching and Leadership.

McNamara, O. \& Murray, J. (2013) The School Direct programme and its implications for research-informed teacher education and teacher educators. York: Higher Education Academy. Menter, I., Brisard, E. \& Smith. I. (2006). Convergence or divergence? Initial teacher education in Scotland and England. Edinburgh: Dunedin Academic Press. 
Menter, I., Hulme, M., Murray, J., Campbell, A., Hextall, I., Jones, M., Mahony, P., Procter, R. \& Wall, K. (2010) Teacher education research in the UK: the state of the art. Swiss Review of Education, 1: 34-48.

Menter, I. \& Murray, J. (2009) Capacity building in teacher education research. Journal of Education for Teachers, 35.4. pp. 315 - 321.

Montgomery, A. \& Smith, A. (2006) Teacher Education in Northern Ireland: Policy Variations Since Devolution. Scottish Educational Review, 37, pp. 46-58.

Moran, Anne (2013) Reconciling professional and political imperatives for teacher education in Northern Ireland in a changing global economy In: Challenges to Teacher Education in Difficult Economic Times: international perspectives. Routledge Taylor \& Francis Group, Abingdon, Oxon UK \& Florence KY USA, pp. 159-172. ISBN 978-0-415-66198-0

Morris, P. (2012) Pick 'n' mix, select and project; policy borrowing and the quest for 'world class' schooling: an analysis of the 2010 schools White Paper. Journal of Education Policy, 27(1), 89107.

Organisation for Economic Co-operation and Development [OECD] (2005) Teachers Matter: Attracting, Developing and Retaining Effective Teachers. Paris: OECD.

Organisation for Economic Co-operation and Development [OECD] (2007) Improving the Quality of Teacher Education. Paris: OECD.

Organisation for Economic Co-operation and Development [OECD] (2011) Lessons from PISA for the United States: strong performers and successful reformers in education.

http://www.oecd.org/dataoecd/32/50/46623978.pdf.

Paine, L., \& Zeichner, K. (2012). The Local and the Global in Reforming Teaching and Teacher Education. Comparative Education Review, 56(4), 569-583.

Popkewitz, T. (Ed.) (1987) Critical Studies in Teacher Education: its folklore, theory and practice. London: Falmer.

Raffe, D. (2005) Devolution and divergence in education policy. In Devolution in Practice: Public Policy Differences within the UK. Newcastle, IPPR North: 52-69.

Raffe, D. \& Byrne, D. (2005) Policy Learning from Home International Comparisons. CES Briefing No. 34, Edinburgh: Centre for Educational Sociology, University of Edinburgh. 
Raffe, D. (2008) As others see us: a commentary on the OECD review of the quality and equity of schooling in Scotland. Scottish Educational Review, 40(1), 22-36.

Schleicher, A. (2011) Building a High-Quality Teaching Profession: Lessons from around the World. Paris, OECD Publishing.

Seddon, T. \& Levin, J.S. (ed.s) (2013) Educators, Professionalism and Politics. Global Transitions, National Spaces and Professional Projects. London: Routledge.

Smithers, A., Robinson, J. \& Coughlin, M. D. (2013) The Good Teacher Training Guide 2013. Centre for Education and Employment Research: University of Buckingham. http://www.alansmithers.com/reports/The_Good_Teacher_Training_Guide_2012.pdf.

Tabberer, R. (2013) A Review of Initial Teacher Training in Wales.

http://wales.gov.uk/topics/educationandskills/publications/wagreviews/review-of-initial-teachertraining-in-wales/?lang=en.

Training and Development Agency for schools [TDA] (2007) Professional Standards for Teachers. London: TDA.

http://webarchive.nationalarchives.gov.uk/20111218081624/http://tda.gov.uk/teacher/developingcareer/professional-standards-guidance/ /media/resources/teacher/professionalstandards/standards_a4.pdf (accessed 20/06/13).

Welsh Assembly Government [WAG] (2004) Iaith Pawb: A National Action Plan for a Bilingual Wales. http://wales.gov.uk/topics/welshlanguage/publications/iaithpawb/?lang=en.

Welsh Assembly Government [WAG] (2008) The Learning Country: Vision into Action. (http://wales.gov.uk/topics/educationandskills/publications/guidance/learningcountry/?lang=en ).

Welsh Assembly Government [WAG] (2009a) Qualified Teacher Status Standards Wales 2009. http://wales.gov.uk/legislation/subordinate/nonsi/educationwales/2009/3220099/?lang=en.

Welsh Assembly Government [WAG] (2009b) Becoming a Qualified Teacher: Handbook of Guidance

http://wales.gov.uk/topics/educationandskills/publications/guidance/becomingateacher/?lang=en.

Welsh Government [WG] (2011) Revised professional standards for education practitioners in Wales. Welsh Government Circular No: 020/2011. September 2011. http://wales.gov.uk/docs/dcells/publications/110830profstandardsen.pdf. 
Welsh Government (2014) Programme for Government: Education. http://wales.gov.uk/about/programmeforgov/education/programme?lang=en

Wilson, E. (2012) Building social capital in teacher education through university-school partnership. In M. Evans, (Ed) (2012) Teacher Education and Pedagogy: theory, policy and practice. Cambridge, Cambridge University Press.

\footnotetext{
${ }^{\mathrm{i}}$ Despite the small numbers enrolled on Teacher First, this route - like Teach for America - has achieved a high profile nationally.

ii The authors would wish to note that the idea of "craft" in the current English discourse, referred to here, is a simplistic one. Other discourses of "craft" often imply high levels of knowledge and skill.
} 